\title{
Periodic Dry Matter Accumulation and Crop Growth Rate of Oat and Lathyrus as Influenced by Integrated Nutrient Management in Intercropping Systems
}

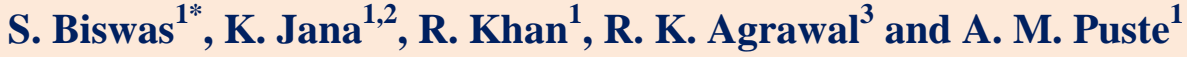 \\ ${ }^{1}$ Department of Agronomy, Bidhan Chandra Krishi Viswavidyalaya, Mohanpur, Nadia, West \\ Bengal-741252, India \\ ${ }^{2}$ AICRP on Forage Crops and Utilization, Directorate of Research, Bidhan Chandra Krishi \\ Viswavidyalaya, Kalyani- 741235, Nadia, West Bengal, India \\ ${ }^{3}$ ICAR-Indian Grassland and Fodder Research Institute (IGFRI), Division of Crop \\ Production, Jhansi-284003, Uttar Pradesh, India \\ *Corresponding author
}

A B S T R A C T

In order to evaluate the effect of integrated nutrient management on periodic dry matter accumulation (DMA) and crop growth rate (CGR) of oat and lathyrus in various intercropping system, one field experiment was exercised at Central Research Farm,

\section{Keywords}

Crop growth rate, Dry matter accumulation, Integrated Nutrient Management,

Intercropping, Lathyrus, Oat

Article Info

Accepted:

22 July 2019

Available Online:

10 August 2019 Gayeshpur, Bidhan Chandra Krishi Viswavidyalaya, Nadia, West Bengal during Rabi season of 2015-16 and 2016-17. The experiment was constructed in split plot design with 3 replications using4 levels of cropping system $\left(\mathrm{CS}_{1}\right.$-Sole oat, $\mathrm{CS}_{2}$-Sole lathyrus, $\mathrm{CS}_{3}$ Intercropping of oat with lathyrus in 3:2 row ratio andCS $4^{-}$Intercropping of oat with lathyrus in 3:3 row ratio)in the main plot and 4 levels of nutrient management $\left(\mathrm{N}_{1}-\right.$ Full RDF through inorganic source, $\mathrm{N}_{2}-75 \% \mathrm{~N}$ through urea + rest $\mathrm{N}$ through FYM, $\mathrm{N}_{3}-75 \%$ $\mathrm{N}$ through urea + rest $\mathrm{N}$ through vermicompost and $\mathrm{N}_{4}-75 \% \mathrm{~N}$ through urea + rest $\mathrm{N}$ through mustard oilcake) in the sub plot. Pooled results depicted that maximum DMA $\left(287.58 \mathrm{~g} / \mathrm{m}^{2}, 175.96 \mathrm{~g} / \mathrm{m}^{2}\right.$ and $288.88 \mathrm{~g} / \mathrm{m}^{2}$ of oat and $182.8 \mathrm{~g} / \mathrm{m}^{2}, 277.26 \mathrm{~g} / \mathrm{m}^{2}$ and 334.39 $\mathrm{g} / \mathrm{m}^{2}$ of lathyrus) was observed at 60,90 and $120 \mathrm{DAS}$ under application of $75 \% \mathrm{~N}$ through urea + rest $\mathrm{N}$ through vermicompost in 3:3 intercropping system and in sole lathyrus respectively. Likewise, consequently CGR for both the crops followed the similar trend. Apart from sole cropping, further lathyrus under 3:3 intercropping system also showed high DMA and CGR at all periodic interval under application of $75 \% \mathrm{~N}$ through urea + rest $\mathrm{N}$ through vermicompost.

\section{Introduction}

India is the residence of a huge population. Agriculture is the backbone of this country. Keeping the ever increasing population pressure in mind, Indian farmers have to produce more and more food as compared to previous year to feed this population. Since agricultural area is being captured daily for human shelter and other activities, horizontal expansion of agriculture is a mirage. Though vertical expansion of agriculture is possible, 
time has come to focus more on 'Intensive cropping' in order to realize increased productivity. Intercropping or simultaneous cultivation of 2 or more crops in a same field with definite row arrangement is one such low input intensive cropping approach which has received considerable attention in recent years especially in India and other developing countries (Lithourgidis et al., 2011) due its several advantages like economization of space and time, greater advantage and stability in yield, insurance against total crop failure, conservation of soil and restoration of its fertility, better water and nutrient use efficiencies (Hauggaard-Nielsen et al., 2001; Agegnehu et al., 2006). Legume is successfully intercropped with cool season fodder grasses in many parts of the world (Dordas et al., 2012). Fodder crop cultivation is though paid less attention, can uplift the rural economy and improve livestock productivity which can be further enjoyed by this enormous population along with agricultural food products. Fortunately, India is gifted with large numbers of livestock and unfortunately its productivity is less than desired (M.S. Puneeth Raj and B.S. Vyakaranahal, 2014). In this context, successful cultivation of fodder crop either alone or in intercropping with legumes is advised. Oat (Avena sativa L.) is one such cool season cereal crop, suited to a variety of agro-climatic situations having high fodder yielding potential (Alemayehu, 1997). Lathyrus (Lathyrus sativus) on the other hand is a winter growing leguminous crop with high biological nitrogen fixing capacity through symbiotic relationship with Rhizobium leguminoseram in their roots and thus can be a suitable option either alone or in intercropping system for restoration of soil health and productivity enhancement of companion as well as follow up crops. Successful growth of these crops is dependent on soil health. But continuous use of inorganic fertilizers in intensive cropping system leads to deterioration of soil quality. Therefore, in order to enhance the accumulation of photosynthates in the form of dry matter which can trigger the rate of crop growth it is necessary to improve soil health at earliest convenience. In this context, integrated nutrient management (INM) using both organic and inorganic nutrient sources is now the priority to the farmers and researchers. Since organic sources are balanced in nature and safe for environment (Chang et al., 1991; Brady, 1996; Chung et al., 2000; Keupper and Gegner, 2004), these are now being widely used in conjunction with inorganic fertilizers for crop production and soil quality improvement. Considering all the above facts and to confirm further, following experiment is planned to evaluate the effect of integrated nutrient management on periodic dry matter accumulation and crop growth rate of oat and lathyrus in intercropping systems.

\section{Materials and Methods}

The field experiment was performed at Central Research Farm, Gayeshpur, Bidhan Chandra Krishi Viswavidyalaya, Nadia, West Bengal $\left(23^{\circ} \mathrm{N}\right.$ latitude, $89^{\circ} \mathrm{E}$ longitude and $9.75 \mathrm{~m}$ above mean sea level and medium land in topography) during winter of 2015-16 and 2016-17in a split plot design consisting 4 levels of cropping system in the main plot $\left(\mathrm{CS}_{1}\right.$-Sole oat, $\mathrm{CS}_{2}$-Sole lathyrus, $\mathrm{CS}_{3}$ Intercropping of oat with lathyrus in 3:2 row ratio andCS $4^{-}$Intercropping of oat with lathyrus in 3:3 row ratio)and 4 levels of nutrient management in the sub plot $\left(\mathrm{N}_{1}-\right.$ Full RDF through inorganic source, $\mathrm{N}_{2}-75 \% \mathrm{~N}$ through urea + rest $\mathrm{N}$ through FYM, $\mathrm{N}_{3}-75 \%$ $\mathrm{N}$ through urea + rest $\mathrm{N}$ through vermicompost and $\mathrm{N}_{4}-75 \% \mathrm{~N}$ through urea + rest $\mathrm{N}$ through mustard oilcake) under 3 replications. The soil was sandy loam textured, neutral in reaction ( $\mathrm{pH}$ 6.75), low in available $\mathrm{N}$ (196.5 kg/ha), high in available $\mathrm{P}$ $(47.2 \mathrm{~kg} / \mathrm{ha})$, medium in available $\mathrm{K}(198.4$ 
$\mathrm{kg} / \mathrm{ha}$ ) and organic carbon (0.51\%).Plot size was 4 m x 3 m. The variety 'OS-6' for oat @ $100 \mathrm{~kg} / \mathrm{ha}, 70 \mathrm{~kg} / \mathrm{ha}, 57 \mathrm{~kg} / \mathrm{ha}$ and 'Ratan' (Bio L 212) for lathyrus @ $50 \mathrm{~kg} / \mathrm{ha}, 15 \mathrm{~kg} / \mathrm{ha}$, $20 \mathrm{~kg} / \mathrm{ha}$ were used in sole cropping, 3:2 and 3:3 intercropping systems, respectively. Recommended doses of fertilizers (RDF) for oat and lathryrus were $80 \mathrm{~kg} \mathrm{~N}, 60 \mathrm{~kg} \mathrm{P}_{2} \mathrm{O}_{5}$ and $40 \mathrm{~kg} \mathrm{~K} \mathrm{~K}_{2} \mathrm{O} / \mathrm{ha}$ and $20 \mathrm{~kg} \mathrm{~N}, 40 \mathrm{~kg} \mathrm{P}_{2} \mathrm{O}_{5}$ and $30 \mathrm{~kg} \quad \mathrm{~K}_{2} \mathrm{O} / \mathrm{ha}$ respectively. In intercropping systems, RDF of main crop oat was used.In oat based cropping systems, 50\% $\mathrm{N}(25 \%$ each from inorganic and organic sources), $100 \% \quad \mathrm{P}_{2} \mathrm{O}_{5}$ and $\mathrm{K}_{2} \mathrm{O}$ (from S.S.P. and M.O.P. respectively) as basal and rest $50 \% \mathrm{~N}$ as two equal top dressing at 25 days after sowing (DAS) and 61 DAS were applied, while in sole lathyrus, entire quantity of nutrients was applied as basal. Green forage of oat was obtained through a cutting made at 60 DAS. Both the crops were harvested at 120 DAS. Observations comprise dry matter accumulation and growth rate of both the crops at a periodic interval of 30 days. The data obtained from the field was undergone statistical analysis using analysis of variance method (Goulden, 1952 and Cochran and Cox, 1959) and critical difference (CD) at 5\% significance level was used to compare treatment means following the method put forwarded by Gomez and Gomez (1984).

\section{Results and Discussion}

\section{Dry matter accumulation and crop growth rate of oat}

Pooled experimental results explored that at 30 DAS there was no significant effect of different types of cropping system on dry matter accumulation (DMA) and crop growth rate (CGR) for the respective 30 days period of oat as during early stage crops had no competition for resources. But from 60 DAS to harvest (120 DAS), those varied significantly with cropping system (Table 1).
However, at 30 DAS maximum dry matter accumulation $\left(80.23 \mathrm{~g} / \mathrm{m}^{2}\right)$ and crop growth rate $\left(2.68 \mathrm{~g} / \mathrm{m}^{2} /\right.$ day)for the respective 30 days period were recorded in intercropping system of oat and lathyrus at 3:3 row ratios $\left(\mathrm{CS}_{4}\right)$. At 60 DAS maximum dry matter accumulation $\left(252.37 \mathrm{~g} / \mathrm{m}^{2}\right)$ and crop growth rate $(5.74$ $\mathrm{g} / \mathrm{m}^{2} /$ day)for the respective 30 days period were observed in intercropping system of oat and lathyrus at 3:3 row ratios $\left(\mathrm{CS}_{4}\right)$ followed by 3:2 intercropping system of oat and lathyrus $\left(\mathrm{CS}_{3}\right)$ and sole oat $\left(\mathrm{CS}_{1}\right)$. At 90 DAS 3:3 intercropping system of oat and lathyrus $\left(\mathrm{CS}_{4}\right)$ again became best with dry matter accumulation $\left(155.98 \mathrm{~g} / \mathrm{m}^{2}\right)$ and crop growth rate $\left(5.20 \mathrm{~g} / \mathrm{m}^{2} /\right.$ day)for the respective 30 days period of oat. The dry matter accumulation and crop growth rate of oat were reduced because at 60 DAS a cutting was made to obtain green forage yield for livestock and as a result, oat required further regeneration. At harvest (120 DAS)maximum dry matter accumulation $\left(250.34 \mathrm{~g} / \mathrm{m}^{2}\right)$ and crop growth rate $\left(3.15 \mathrm{~g} / \mathrm{m}^{2} /\right.$ day)for the respective 30 days period were found in intercropping system of oat and lathyrus at 3:3 row ratios $\left(\mathrm{CS}_{4}\right)$ followed by 3:2 intercropping system of oat and lathyrus $\left(\mathrm{CS}_{3}\right)$ and sole oat $\left(\mathrm{CS}_{1}\right)$. Progression towards maturity might be the reason for less dry matter accumulation and crop growth rate of oat at harvest. Dry matter accumulation of oat was lowest in case of sole oat $\left(\mathrm{CS}_{1}\right)$ because there was no leguminous crop lathyrus to undergo biological nitrogen fixation while in contrast under both the intercropping systems due to biological nitrogen fixation by lathyrus, oat accumulated more dry matter and accordingly crop growth rate varied among the cropping systems. However, 3:3 intercropping system of oat and lathyrus $\left(\mathrm{CS}_{4}\right)$ was superior over another intercropping system due to more lathyrus population to undergo higher biological nitrogen fixation. The benefit of cereal legume intercropping system on above ground biomass and crop growth rate of cereals was 
also reported by Verdelli et al., (2012) in corn-soybean intercropping system. Findings of Yang et al., (2018) on maize-pea intercropping system was also in agreement with this result. Likewise at 30 DAS there was no significant influence of different levels of nutrient management on dry matter accumulation of oat and crop growth rate for the respective 30 days period. The highest dry matter accumulation $\left(80.27 \mathrm{~g} / \mathrm{m}^{2}\right)$ and crop growth rate $\left(2.68 \mathrm{~g} / \mathrm{m}^{2} /\right.$ day $)$ for the respective 30 days period were observed in $75 \% \mathrm{~N}$ through urea + rest $\mathrm{N}$ through vermicompost $\left(\mathrm{N}_{3}\right)$ followed by $75 \% \mathrm{~N}$ through urea + rest $\mathrm{N}$ through mustard oilcake $\left(\mathrm{N}_{4}\right), 75 \% \mathrm{~N}$ through urea + rest $\mathrm{N}$ through FYM $\left(\mathrm{N}_{2}\right)$ and full RDF through inorganic source $\left(\mathrm{N}_{1}\right)$.

However, dry matter accumulation and crop growth rate varied significantly with different levels of nutrient management from 60 DAS to harvest (120 DAS) (Table 1). Highest dry matter accumulation $\left(246.87 \mathrm{~g} / \mathrm{m}^{2}\right)$ at 60 DAS and crop growth rate $\left(5.55 \mathrm{~g} / \mathrm{m}^{2} /\right.$ day)for the respective 30 days period were noticed in $75 \%$ $\mathrm{N}$ through urea + rest $\mathrm{N}$ through vermicompost $\left(\mathrm{N}_{3}\right)$ followed by $75 \% \mathrm{~N}$ through urea + rest $\mathrm{N}$ through mustard oilcake $\left(\mathrm{N}_{4}\right), 75 \% \mathrm{~N}$ through urea + rest $\mathrm{N}$ through FYM $\left(\mathrm{N}_{2}\right)$ and full RDF through inorganic source $\left(\mathrm{N}_{1}\right)$. In respect of dry matter accumulation and crop growth rate of oat, treatments $\mathrm{N}_{2}$ and $\mathrm{N}_{4}$ were statistically at par with each other and treatments $\mathrm{N}_{1}$ and $\mathrm{N}_{2}$ were statistically at par with each other. At 90 DAS again highest dry matter accumulation $\left(151.43 \mathrm{~g} / \mathrm{m}^{2}\right)$ and crop growth rate $(5.05$ $\mathrm{g} / \mathrm{m}^{2} /$ day) for the respective 30 days period were obtained from $75 \% \mathrm{~N}$ through urea + rest $\mathrm{N}$ through vermicompost $\left(\mathrm{N}_{3}\right)$ followed by $75 \% \mathrm{~N}$ through urea + rest $\mathrm{N}$ through mustard oilcake $\left(\mathrm{N}_{4}\right), 75 \% \mathrm{~N}$ through urea + rest $\mathrm{N}$ through FYM $\left(\mathrm{N}_{2}\right)$ and full RDF through inorganic source $\left(\mathrm{N}_{1}\right)$. Treatment $\mathrm{N}_{2}$ was statistically at par with treatment $\mathrm{N}_{4}$ in terms of both dry matter accumulation and crop growth rate of oat. During harvest (120 DAS) also $75 \% \mathrm{~N}$ through urea + rest $\mathrm{N}$ through vermicompost $\left(\mathrm{N}_{3}\right)$ proved to be the best with dry matter accumulation $\left(246.19 \mathrm{~g} / \mathrm{m}^{2}\right)$ of oat and crop growth rate $\left(3.16 \mathrm{~g} / \mathrm{m}^{2} /\right.$ day) for the respective 30 days period followed by $75 \% \mathrm{~N}$ through urea + rest $\mathrm{N}$ through mustard oilcake $\left(\mathrm{N}_{4}\right), 75 \% \mathrm{~N}$ through urea + rest $\mathrm{N}$ through FYM $\left(\mathrm{N}_{2}\right)$ and full RDF through inorganic source $\left(\mathrm{N}_{1}\right)$. Treatment $\mathrm{N}_{2}$ was statistically at par with treatment $\mathrm{N}_{4}$ in terms of dry matter accumulation and crop growth rate of oat. Crop growth rate of oat under treatment $\mathrm{N}_{1}$ was at par statistically with that under treatment $\mathrm{N}_{2}$.Positive effect of vermicompost in mobilisation and availability of nutrients for plant uptake might be the reason behind the best result obtained through application of $75 \% \mathrm{~N}$ through urea + rest $\mathrm{N}$ through vermicompost $\left(\mathrm{N}_{3}\right)$. Vasanthi and Kumaraswamy (1996) also mentioned the positive effect of vermicompost on soil and crops. Excellent growth rate and DMA of oat from integrated nutrient management (INM) using vermicompost was also possibly because of presence of some growth promoters in worm casts (Tomati et al., 1995). The results corroborated the findings of Puneeth Raj and Vyakaranahal (2014).

\section{Interaction effect of cropping system and nutrient management on DMA and CGR of oat}

Interaction effect between cropping system and nutrient management on dry matter accumulation (DMA) and crop growth rate (CGR) of oat was not observed during first 30 days of cultivation. However, afterwards, both cropping system and nutrient management jointly exerted significant effect on DMA and CGR of oat up to harvest (120 DAS). At every 30 days periodic interval, highest DMA and consequently CGR of oat were noticed when $75 \% \mathrm{~N}$ through urea + rest $\mathrm{N}$ through vermicompost $\left(\mathrm{N}_{3}\right)$ was applied in $3: 3$ 
intercropping system of oat and lathyrus $\left(\mathrm{CS}_{4}\right)$. Pooled results of 2 years revealed that specifically, among all, at 60, 90 and 120 DAS, the above mentioned treatment combination $\left(\mathrm{CS}_{4} \mathrm{~N}_{3}\right)$ exhibited highest DMA of $287.58 \mathrm{~g} / \mathrm{m}^{2}, 175.96 \mathrm{~g} / \mathrm{m}^{2}$ and $288.88 \mathrm{~g} / \mathrm{m}^{2}$ respectively and in consequence, CGR of 6.91 $\mathrm{g} / \mathrm{m}^{2} /$ day, $5.87 \mathrm{~g} / \mathrm{m}^{2} /$ day and $3.76 \mathrm{~g} / \mathrm{m}^{2} /$ day for 30-60 DAS, 60-90 DAS and 90-120 DAS periods respectively which was followed by $\mathrm{CS}_{4} \mathrm{~N}_{4}$ combination i.e. $75 \% \mathrm{~N}$ through urea + rest $\mathrm{N}$ through mustard oilcake $\left(\mathrm{N}_{4}\right)$ applied in 3:3 intercropping system of oat and lathyrus $\left(\mathrm{CS}_{4}\right)$ (Table 2).Full RDF through inorganic source $\left(\mathrm{N}_{1}\right)$ when applied in sole oat $\left(\mathrm{CS}_{1}\right)$ i.e. $\mathrm{CS}_{1} \mathrm{~N}_{1}$ combination, recorded lowest DMA and CGR of oat at all the mentioned periods. Positive effect of vermicompost in nodule activity of legume crop lathyrus in intercropping system especially at 3:3 with more lathyrus population compared to $3: 2$ intercropping system might be the reason behind increment of DMA and CGR of cereal crop oat $\left(\mathrm{CS}_{4} \mathrm{~N}_{3}\right)$ as the crop obtained nutrition from both biological nitrogen fixation and integrated sources of nutrients using vermicompost.

\section{Dry matter accumulation and crop growth rate of lathyrus}

Similar to oat, there was also no significant variation on dry matter accumulation (DMA) at 30 DAS and crop growth rate (CGR) for the respective 30 days period of lathyrus. However, among the cropping systems, sole lathyrus recorded maximum dry matter accumulation $\left(49.39 \mathrm{~g} / \mathrm{m}^{2}\right.$ ) and crop growth rate $\left(1.65 \mathrm{~g} / \mathrm{m}^{2} /\right.$ day $)$ for the respective 30 days period. From 60 DAS onwards cropping systems showed significant effect on DMA and CGR of lathyrus. At 60 DAS maximum dry matter accumulation $\left(173.90 \mathrm{~g} / \mathrm{m}^{2}\right)$ and crop growth rate for the respective 30 days period of lathyrus $\left(4.15 \mathrm{~g} / \mathrm{m}^{2} /\right.$ day $)$ were observed in the sole lathyrus $\left(\mathrm{CS}_{2}\right)$ followed by 3:3 intercropping system of oat and lathyrus $\left(\mathrm{CS}_{4}\right)$ and 3:2 intercropping system of oat and lathyrus $\left(\mathrm{CS}_{3}\right)$ (Table 3). At 90 DAS also sole lathyrus $\left(\mathrm{CS}_{2}\right)$ was the best cropping system with dry matter accumulation of $247.30 \mathrm{~g} / \mathrm{m}^{2}$ and crop growth rate of 2.45 $\mathrm{g} / \mathrm{m}^{2} /$ dayfor the respective 30 days period. However, crop growth rates in both the intercropping system were statistically at par with each other. It was because of that at 60 DAS a cutting was done in case of oat crop to obtain green forage yield and oat had to regenerate again resulting in no shading effect in both intercropping systems. At 120 DAS (at harvest) maximum dry matter accumulation $\left(296.50 \mathrm{~g} / \mathrm{m}^{2}\right)$ was observed in the sole lathyrus $\left(\mathrm{CS}_{2}\right)$ followed by 3:3 intercropping system of oat and lathyrus $\left(\mathrm{CS}_{4}\right)$ and $3: 2$ intercropping system of oat and lathyrus $\left(\mathrm{CS}_{3}\right)$. Crop growth rate for 90-120 DAS period also followed the similar trend with highest rate being $1.64 \mathrm{~g} / \mathrm{m}^{2} /$ day and both the intercropping system were statistically at par with each other. This result proved that as the crop progressed towards maturity, its metabolic activity got reduced resulting in decrement of growth rate. Sole lathyrus was best as there was no intercrop competition with cereal crop oat. Patra et al., (1999) explained that no shading effect in sole cropping of legume crops attributed better results compared to intercropping system using maize which corroborated the present findings. Nitrogen fixed biologically by lathyrus was utilized by lathyrus only. But in both the intercropping system, transfer of nitrogen fixed by lathyrus to oat took place. Eaglesham et al., (1981) also reported the same in maize-cowpea intercropping system. However, 3:3 intercropping system of oat and lathyrus was better intercropping system over the other as more lathyrus population was there to fix more atmospheric nitrogen biologically which inflected better dry matter accumulation and helped in attaining higher growth rate of lathyrus. 
Table.1 Effect of different levels of cropping system and nutrient management on dry matter accumulation and crop growth rate of oat (Pooled of 2 years)

\begin{tabular}{|c|c|c|c|c|c|c|c|c|}
\hline \multirow[t]{2}{*}{ Treatment } & \multicolumn{4}{|c|}{ Dry Matter Accumulation $\left(\mathrm{g} / \mathrm{m}^{2}\right)$} & \multicolumn{4}{|c|}{ Crop growth rate (g/m²/day) } \\
\hline & 30 DAS & 60 DAS & 90 DAS & 120 DAS & 0-30 DAS & 30-60 DAS & 60-90 DAS & 90-120 DAS \\
\hline \multicolumn{9}{|c|}{ Levels of cropping system (CS) } \\
\hline $\mathbf{C S}_{1}$ & 80.18 & 209.29 & 124.65 & 200.06 & 2.67 & 4.30 & 4.16 & 2.51 \\
\hline $\mathbf{C S}_{3}$ & 80.19 & 223.57 & 139.91 & 227.33 & 2.67 & 4.78 & 4.66 & 2.91 \\
\hline $\mathrm{CS}_{4}$ & 80.23 & 252.37 & 155.98 & 250.34 & 2.68 & 5.74 & 5.20 & 3.15 \\
\hline S.Em $( \pm)$ & 0.061 & 2.91 & 1.61 & 2.52 & 0.042 & 0.100 & 0.054 & 0.067 \\
\hline $\begin{array}{c}\text { CD } \\
(p=0.05)\end{array}$ & NS & 11.45 & 6.34 & 9.89 & NS & 0.391 & 0.211 & 0.262 \\
\hline \multicolumn{9}{|c|}{ Levels of nutrient management $(\mathrm{N})$} \\
\hline $\mathbf{N}_{1}$ & 80.04 & 214.76 & 130.33 & 210.78 & 2.66 & 4.49 & 4.34 & 2.68 \\
\hline $\mathbf{N}_{2}$ & 80.22 & 224.18 & 137.18 & 220.52 & 2.67 & 4.80 & 4.57 & 2.78 \\
\hline $\mathbf{N}_{3}$ & 80.27 & 246.87 & 151.43 & 246.19 & 2.68 & 5.55 & 5.05 & 3.16 \\
\hline $\mathbf{N}_{4}$ & 80.24 & 227.82 & 141.77 & 226.15 & 2.67 & 4.92 & 4.73 & 2.81 \\
\hline S.Em ( $( \pm)$ & 0.083 & 3.66 & 2.09 & 3.81 & 0.053 & 0.122 & 0.070 & 0.095 \\
\hline $\begin{array}{c}\text { CD } \\
(p=0.05)\end{array}$ & NS & 10.89 & 6.20 & 7.99 & NS & 0.364 & 0.207 & 0.283 \\
\hline
\end{tabular}

$\mathrm{CS}_{1}-$ Sole oat, $\mathrm{CS}_{2}-$ Sole Lathyrus, $\mathrm{CS}_{3}-$ Oat + Lathyrus as 3:2 intercropping, $\mathrm{CS}_{4}-$ Oat + Lathyrus as 3:3 intercropping and $\mathrm{N}_{1}-$ Full RDF through inorganic source, $\mathrm{N}_{2}-75 \% \mathrm{~N}$ through urea + rest $\mathrm{N}$ through $\mathrm{FYM}, \mathrm{N}_{3}-75 \% \mathrm{~N}$ through urea + rest $\mathrm{N}$ through vermicompost and $\mathrm{N}_{4}-75 \% \mathrm{~N}$ through urea + rest $\mathrm{N}$ through mustard oilcake, respectively. 
Table.2 Interaction effect of different levels of cropping system and nutrient management on dry matter accumulation and crop growth rate of oat (Pooled of 2 years)

\begin{tabular}{|c|c|c|c|c|c|c|c|c|c|c|c|c|}
\hline \multirow{2}{*}{$\begin{array}{c}\text { Treatment } \\
\text { combination(s) }\end{array}$} & \multicolumn{6}{|c|}{ Dry Matter Accumulation $\left(\mathrm{g} / \mathrm{m}^{2}\right)$} & \multicolumn{6}{|c|}{ Crop growth rate $\left(\mathrm{g} / \mathrm{m}^{2} / \mathrm{day}\right)$} \\
\hline & \multicolumn{2}{|c|}{60 DAS } & \multicolumn{2}{|c|}{90 DAS } & \multicolumn{2}{|c|}{120 DAS } & \multicolumn{2}{|c|}{ 30-60 DAS } & \multicolumn{2}{|c|}{ 60-90 DAS } & \multicolumn{2}{|c|}{ 90-120 DAS } \\
\hline $\mathrm{CS}_{1} \mathrm{~N}_{1}$ & \multicolumn{2}{|c|}{192.06} & \multicolumn{2}{|c|}{112.66} & \multicolumn{2}{|c|}{197.60} & \multicolumn{2}{|c|}{3.73} & \multicolumn{2}{|c|}{3.76} & \multicolumn{2}{|c|}{2.83} \\
\hline $\mathrm{CS}_{1} \mathbf{N}_{2}$ & \multicolumn{2}{|c|}{209.53} & \multicolumn{2}{|c|}{121.93} & \multicolumn{2}{|c|}{190.39} & \multicolumn{2}{|c|}{4.31} & \multicolumn{2}{|c|}{4.06} & \multicolumn{2}{|c|}{2.28} \\
\hline $\mathrm{CS}_{1} \mathbf{N}_{3}$ & \multicolumn{2}{|c|}{219.46} & \multicolumn{2}{|c|}{135.02} & \multicolumn{2}{|c|}{211.13} & \multicolumn{2}{|c|}{4.64} & \multicolumn{2}{|c|}{4.50} & \multicolumn{2}{|c|}{2.54} \\
\hline $\mathrm{CS}_{1} \mathrm{~N}_{4}$ & \multicolumn{2}{|c|}{216.10} & \multicolumn{2}{|c|}{128.98} & \multicolumn{2}{|c|}{201.10} & \multicolumn{2}{|c|}{4.53} & \multicolumn{2}{|c|}{4.30} & \multicolumn{2}{|c|}{2.40} \\
\hline $\mathrm{CS}_{3} \mathrm{~N}_{1}$ & \multicolumn{2}{|c|}{212.81} & 13 & .38 & & .80 & & & & & & \\
\hline $\mathrm{CS}_{3} \mathrm{~N}_{2}$ & 222 & & 14 & 96 & & .48 & & & & & & \\
\hline $\mathrm{CS}_{3} \mathbf{N}_{3}$ & 23 & & 14 & 32 & & .56 & & & & & & \\
\hline $\mathrm{CS}_{3} \mathbf{N}_{4}$ & 22 & & 14 & 96 & & .50 & & & & & & \\
\hline $\mathrm{CS}_{4} \mathbf{N}_{1}$ & 23 & & 14 & & & .95 & & & & & & \\
\hline $\mathrm{CS}_{4} \mathrm{~N}_{2}$ & 240 & & 14 & 66 & & 69 & & & & & & \\
\hline $\mathrm{CS}_{4} \mathrm{~N}_{3}$ & 28 & & & 96 & & .88 & & & & & & \\
\hline $\mathrm{CS}_{4} \mathrm{~N}_{4}$ & 24 & & & & & .85 & & & & & & \\
\hline Interaction & CS X N & N XCS & CS X N & N XCS & CS X N & N XCS & CS X N & N X CS & CS X N & N X CS & CS X N & $\mathbf{N} \times \mathbf{C S}$ \\
\hline S.Em $( \pm)$ & 6.35 & 6.23 & 3.62 & 3.52 & 4.66 & 4.76 & 0.212 & 0.209 & 0.121 & 0.117 & 0.165 & 0.158 \\
\hline $\mathrm{CD}(p=0.05)$ & 18.87 & 19.81 & 10.75 & 11.17 & 13.85 & 15.41 & 0.630 & 0.666 & 0.358 & 0.373 & 0.489 & 0.495 \\
\hline
\end{tabular}

$\mathrm{CS}_{1}-$ Sole oat, $\mathrm{CS}_{2}-$ Sole Lathyrus, $\mathrm{CS}_{3}-$ Oat + Lathyrus as 3:2 intercropping, $\mathrm{CS}_{4}-$ Oat + Lathyrus as 3:3 intercropping and $\mathrm{N}_{1}-$ Full RDF through inorganic source, $\mathrm{N}_{2}-75 \% \mathrm{~N}$ through urea + rest $\mathrm{N}$ through $\mathrm{FYM}, \mathrm{N}_{3}-75 \% \mathrm{~N}$ through urea + rest $\mathrm{N}$ through vermicompost and $\mathrm{N}_{4}-75 \% \mathrm{~N}$ through urea + rest $\mathrm{N}$ through mustard oilcake, respectively. 
Table.3 Effect of different levels of cropping system and nutrient management on dry matter accumulation and crop growth rate of lathyrus (Pooled of 2 years)

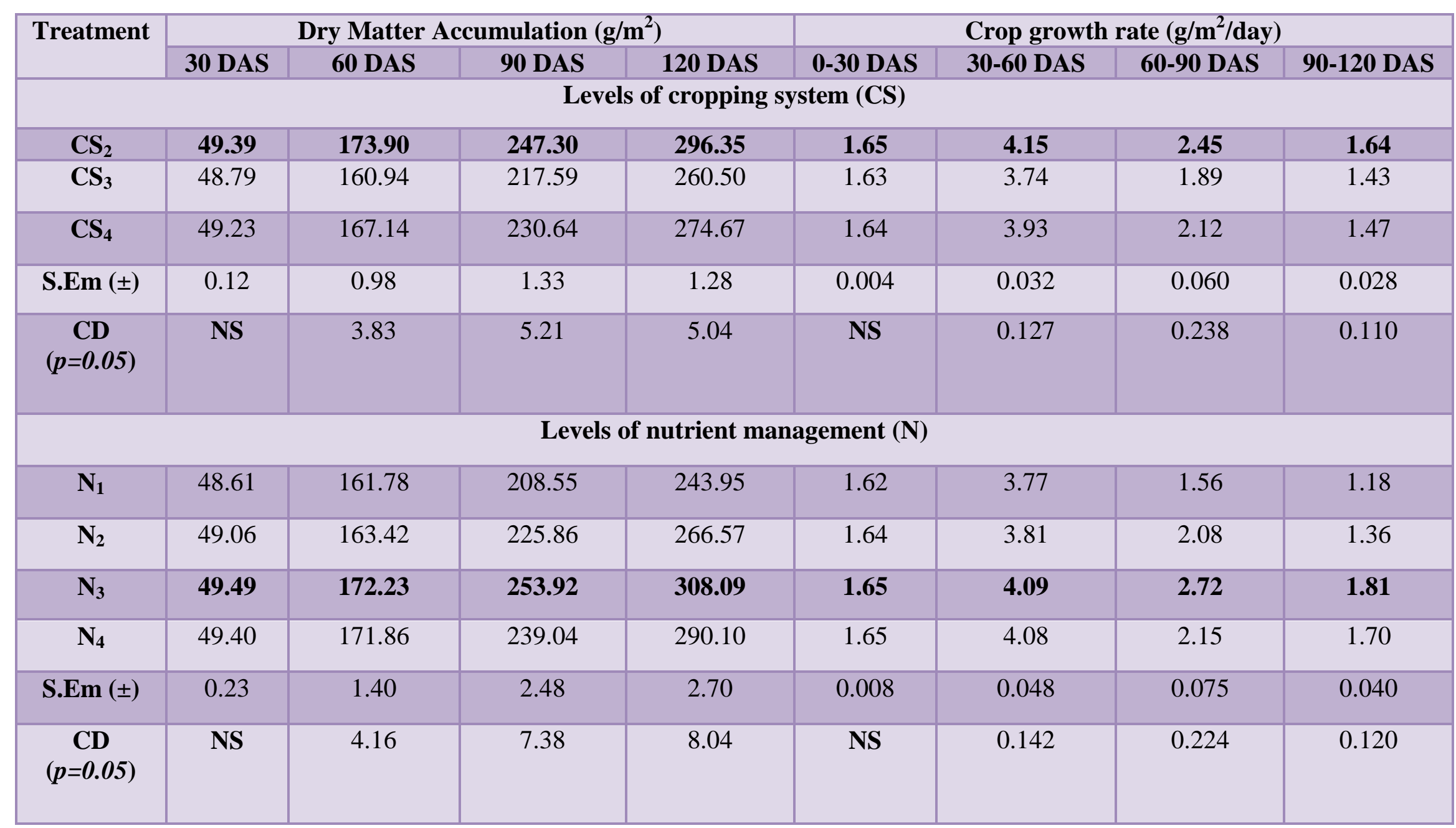

$\mathrm{CS}_{1}$ - Sole oat, $\mathrm{CS}_{2}-$ Sole Lathyrus, $\mathrm{CS}_{3}-$ Oat + Lathyrus as 3:2 intercropping, $\mathrm{CS}_{4}-$ Oat + Lathyrus as 3:3 intercropping and $\mathrm{N}_{1}-$ Full RDF through inorganic source, $\mathrm{N}_{2}-75 \% \mathrm{~N}$ through urea + rest $\mathrm{N}$ through $\mathrm{FYM}, \mathrm{N}_{3}-75 \% \mathrm{~N}$ through urea + rest $\mathrm{N}$ through vermicompost and $\mathrm{N}_{4}-75 \% \mathrm{~N}$ through urea + rest $\mathrm{N}$ through mustard oilcake, respectively. 
Table.4 Interaction effect of different levels of cropping system and nutrient management on dry matter accumulation and crop growth rate of lathyrus (Pooled of 2 years)

\begin{tabular}{|c|c|c|c|c|c|c|c|c|c|c|c|c|}
\hline \multirow{2}{*}{$\begin{array}{c}\text { Treatment } \\
\text { combination(s) }\end{array}$} & \multicolumn{6}{|c|}{ Dry Matter Accumulation $\left(\mathrm{g} / \mathrm{m}^{2}\right)$} & \multicolumn{6}{|c|}{ Crop growth rate $\left(\mathrm{g} / \mathrm{m}^{2} / \mathrm{day}\right)$} \\
\hline & \multicolumn{2}{|c|}{60 DAS } & \multicolumn{2}{|c|}{90 DAS } & \multicolumn{2}{|c|}{120 DAS } & \multicolumn{2}{|c|}{ 30-60 DAS } & \multicolumn{2}{|c|}{ 60-90 DAS } & \multicolumn{2}{|c|}{ 90-120 DAS } \\
\hline $\mathrm{CS}_{2} \mathrm{~N}_{1}$ & \multicolumn{2}{|c|}{165.55} & \multicolumn{2}{|c|}{213.37} & \multicolumn{2}{|c|}{252.88} & \multicolumn{2}{|c|}{3.88} & \multicolumn{2}{|c|}{1.59} & \multicolumn{2}{|c|}{1.32} \\
\hline $\mathrm{CS}_{2} \mathbf{N}_{2}$ & \multicolumn{2}{|c|}{165.15} & \multicolumn{2}{|c|}{236.36} & \multicolumn{2}{|c|}{283.50} & \multicolumn{2}{|c|}{3.87} & \multicolumn{2}{|c|}{2.37} & \multicolumn{2}{|c|}{1.57} \\
\hline $\mathbf{C S}_{2} \mathbf{N}_{3}$ & \multicolumn{2}{|c|}{182.84} & \multicolumn{2}{|c|}{277.26} & \multicolumn{2}{|c|}{334.39} & \multicolumn{2}{|c|}{4.45} & \multicolumn{2}{|c|}{3.17} & \multicolumn{2}{|c|}{1.90} \\
\hline $\mathrm{CS}_{2} \mathrm{~N}_{4}$ & \multicolumn{2}{|c|}{182.05} & \multicolumn{2}{|c|}{262.22} & \multicolumn{2}{|c|}{314.65} & \multicolumn{2}{|c|}{4.40} & \multicolumn{2}{|c|}{2.65} & \multicolumn{2}{|c|}{1.75} \\
\hline $\mathrm{CS}_{3} \mathrm{~N}_{1}$ & \multicolumn{2}{|c|}{159.06} & 199 & 94 & 23 & 61 & & & & & & \\
\hline $\mathrm{CS}_{3} \mathbf{N}_{2}$ & 15 & & 215 & 22 & 24 & .65 & & & & & & \\
\hline $\mathrm{CS}_{3} \mathrm{~N}_{3}$ & 16 & & 227 & & 28 & .25 & & & & & & \\
\hline $\mathrm{CS}_{3} \mathrm{~N}_{4}$ & 16 & & 227 & & 278 & .51 & & & & & & \\
\hline $\mathrm{CS}_{4} \mathrm{~N}_{1}$ & 16 & & 212 & & 24 & .36 & & & & & & \\
\hline $\mathrm{CS}_{4} \mathbf{N}_{2}$ & 16 & & 226 & .00 & 268 & .57 & & & & & & \\
\hline $\mathrm{CS}_{4} \mathbf{N}_{3}$ & 17 & & 250 & & 308 & .63 & & & & & & \\
\hline $\mathrm{CS}_{4} \mathbf{N}_{4}$ & 16 & & 227 & & 277 & .14 & & & & & & \\
\hline Interaction & CS X N & N XCS & CS X N & N XCS & CS X N & N XCS & CS X N & N X CS & $\underset{\mathbf{N}}{\mathbf{C S} X}$ & $\begin{array}{c}\mathbf{N X} \\
\mathbf{C S}\end{array}$ & $\begin{array}{c}\text { CS X } \\
\mathbf{N}\end{array}$ & $\begin{array}{c}\text { N X } \\
\text { CS }\end{array}$ \\
\hline S.Em ( \pm$)$ & 2.42 & 2.32 & 4.30 & 3.96 & 4.69 & 4.26 & 0.083 & 0.079 & 0.131 & 0.128 & 0.070 & 0.067 \\
\hline $\mathrm{CD}(p=0.05)$ & 7.20 & 7.27 & 12.78 & 12.18 & 13.92 & 13.01 & 0.246 & 0.246 & 0.388 & 0.409 & 0.207 & 0.209 \\
\hline
\end{tabular}

$\mathrm{CS}_{1}-$ Sole oat, $\mathrm{CS}_{2}-$ Sole Lathyrus, $\mathrm{CS}_{3}-$ Oat + Lathyrus as 3:2 intercropping, $\mathrm{CS}_{4}-$ Oat + Lathyrus as 3:3 intercropping and $\mathrm{N}_{1}-$ Full RDF through inorganic source, $\mathrm{N}_{2}-75 \% \mathrm{~N}$ through urea + rest $\mathrm{N}$ through FYM, $\mathrm{N}_{3}-75 \% \mathrm{~N}$ through urea + rest $\mathrm{N}$ through vermicompost and $\mathrm{N}_{4}-75 \% \mathrm{~N}$ through urea + rest $\mathrm{N}$ through mustard oilcake, respectively. 
Moghaddam et al., (2014) also confirmed positive relation between biological nitrogen fixation and crop growth in alfalfa.

Different nutrient management options also posed no significant effect on DMA of lathyrus at $30 \mathrm{DAS}$ and CGR for the period of first 30 days. But, maximum dry matter accumulation (49.49 $\mathrm{g} / \mathrm{m}^{2}$ ) and crop growth rate $\left(1.65 \mathrm{~g} / \mathrm{m}^{2} /\right.$ day $)$ were recorded from $75 \%$ $\mathrm{N}$ through urea + rest $\mathrm{N}$ through vermicompost $\left(\mathrm{N}_{3}\right)$.However, significant response was noticed afterwards (Table 3).At 60 DAS highest dry matter accumulation of lathyrus $\left(172.23 \mathrm{~g} / \mathrm{m}^{2}\right)$ and crop growth rate $\left(4.09 \mathrm{~g} / \mathrm{m}^{2} /\right.$ day) for respective 30 days period were found in $75 \% \mathrm{~N}$ through urea + rest $\mathrm{N}$ through vermicompost $\left(\mathrm{N}_{3}\right)$ followed by $75 \%$ $\mathrm{N}$ through urea + rest $\mathrm{N}$ through mustard oilcake $\left(\mathrm{N}_{4}\right), 75 \% \mathrm{~N}$ through urea + rest $\mathrm{N}$ through FYM $\left(\mathrm{N}_{2}\right)$ and full RDF through inorganic source $\left(\mathrm{N}_{1}\right)$. Treatment $\mathrm{N}_{1}$ was statistically at par with treatment $\mathrm{N}_{2}$ and treatment $\mathrm{N}_{4}$ was statistically at par with treatment $\mathrm{N}_{3}$ in terms of both the growth attributes. The highest dry matter accumulation $\left(253.92 \mathrm{~g} / \mathrm{m}^{2}\right)$ at 90 DAS and crop growth rate $\left(2.72 \mathrm{~g} / \mathrm{m}^{2} /\right.$ day $)$ of lathyrus for 60-90 DAS were noticed again in $75 \% \mathrm{~N}$ through urea + rest $\mathrm{N}$ through vermicompost $\left(\mathrm{N}_{3}\right)$ followed by $75 \% \mathrm{~N}$ through urea + rest $\mathrm{N}$ through mustard oilcake $\left(\mathrm{N}_{4}\right), 75 \% \mathrm{~N}$ through urea + rest $\mathrm{N}$ through FYM $\left(\mathrm{N}_{2}\right)$ and full RDF through inorganic source $\left(\mathrm{N}_{1}\right)$.

At the time of harvesting (120 DAS) also $75 \% \mathrm{~N}$ through urea + rest $\mathrm{N}$ through vermicompost $\left(\mathrm{N}_{3}\right)$ showed its superiority over the others with highest dry matter accumulation $\left(308.09 \mathrm{~g} / \mathrm{m}^{2}\right)$ of lathyrus and crop growth rate $\left(1.81 \mathrm{~g} / \mathrm{m}^{2} /\right.$ day) for $90-120$ DAS. This result obtained might be due to the presence of vermicompost in INM option $\left(\mathrm{N}_{3}\right)$ as vermicompost is a rich source of nutrients which can enhance activity of beneficial soil microorganisms (Rajkhowa et al., 2000).
Further it helps in root proliferation permitting higher availability of nutrients for uptake, synthesis and translocation of carbohydrates that enhance vegetative growth of plants (Khan et al., 2017).Different types of enzymes present in vermicompost improve rhizobial activity of legumes and help in production of increased number of nodules to carry out biological nitrogen fixation. Similar type of observation was also noticed by Bajracharya and Rai (2009) in chick pea.

Interaction effect of cropping system and nutrient management on DMA and CGR of lathyrus

Like oat, in lathyrus also during first 30 days, no significant effect of interaction between cropping system and nutrient management on dry matter accumulation (DMA) and crop growth rate (CGR) was noticed. But afterwards up to harvest (120 DAS), interaction effect between cropping system and nutrient management on DMA and CGR of lathyrus became prominent. Sole lathyrus $\left(\mathrm{CS}_{2}\right)$ under application of $75 \% \mathrm{~N}$ through urea + rest $\mathrm{N}$ through vermicompost $\left(\mathrm{N}_{3}\right)$ showed highest DMA and CGR in each interval.

It might be due to the fact that lathyrus under sole cropping because of more population, undergone high biological nitrogen fixation which was accelerated further through improved nodulation by application of vermicompost from INM option. At 60, 90 and 120 DAS, maximum DMA of $182.8 \mathrm{~g} / \mathrm{m}^{2}$, $277.26 \mathrm{~g} / \mathrm{m}^{2}$ and $334.39 \mathrm{~g} / \mathrm{m}^{2}$ respectively and CGR of $4.45 \mathrm{~g} / \mathrm{m}^{2} /$ day, $3.17 \mathrm{~g} / \mathrm{m}^{2} /$ day and $1.90 \mathrm{~g} / \mathrm{m}^{2} /$ day for 30-60 DAS, 60-90 DAS and 90-120 DAS periods(pooled of 2 years) were recorded from $\mathrm{CS}_{2} \mathrm{~N}_{3}$ combination which was followed by $\mathrm{CS}_{2} \mathrm{~N}_{4}$ combination i.e. $75 \% \mathrm{~N}$ through urea + rest $\mathrm{N}$ through mustard oilcake $\left(\mathrm{N}_{4}\right)$ applied in sole lathyrus $\left(\mathrm{CS}_{2}\right)$ (Table 4).However, among two 
intercropping system, 3:3 intercropping system of oat and lathyrus $\left(\mathrm{CS}_{4}\right)$ exhibited higher DMA of $171.25 \mathrm{~g} / \mathrm{m}^{2}, 256.59 \mathrm{~g} / \mathrm{m}^{2}$ and $308.63 \mathrm{~g} / \mathrm{m}^{2}$ respectively at 60,90 and 120 DAS and CGR of $4.06 \mathrm{~g} / \mathrm{m}^{2} /$ day, 2.84 $\mathrm{g} / \mathrm{m}^{2} /$ day and 1.73 for $30-60$ DAS, 60-90 DAS and 90-120 DAS periods respectively when $75 \% \mathrm{~N}$ through urea + rest $\mathrm{N}$ through vermicompost $\left(\mathrm{N}_{3}\right)$ was applied $\left(\mathrm{CS}_{4} \mathrm{~N}_{3}\right)$ (pooled of 2 years).

Lowest DMA and CGR of lathyrus were found in 3:2 intercropping system of oat and lathyrus $\left(\mathrm{CS}_{3}\right)$ under application of $75 \% \mathrm{~N}$ through urea + rest $\mathrm{N}$ through FYM $\left(\mathrm{N}_{2}\right)$ i.e. $\mathrm{CS}_{3} \mathrm{~N}_{2}$ combination.3:3 intercropping system performed better than 3:2 intercropping system under application of $75 \% \mathrm{~N}$ through urea + rest $\mathrm{N}$ through vermicompostas integrated approach of nutrition using vermicompost not only provided various nutrients but also improved nodule activity of comparatively more lathyrus population consisting more number of nodules which in turn improved biological nitrogen fixation in that system.

Further, due to comparatively less shading effect from cereal crop oat, lathyrus in 3:3 intercropping system received more sunlight than 3:2 intercropping system to undergo photosynthesis and transpiration urging for more and more uptake of water from soil. Nutrients present in soil solution through that uptake improved DMA and CGR of lathyrus and those nutrients were readily supplied by vermicompost included INM option along with beneficial role of biological nitrogen fixation.

Based on the pooled results of two years of experiment, it can be concluded that both intercropping and integrated nutrient management options have marked influence on drymatter accumulation and growth rate of oat and lathyrus.
Combined application of $75 \%$ nitrogen through urea and $25 \%$ nitrogen from vermicompost in 3:3 intercropping system of oat and lathyrus performed the best and thus can be recommended to the farmers in order to achieve maximum dry matter accumulation and growth rate of both oat and lathyrus.

\section{References}

Agegnehu, G., Ghizaw, A. and Sinebo, W., 2006. Yield performance and land-use efficiency of barley and faba bean mixed cropping in Ethiopian highlands. European Journal of Agronomy, 25(3): 202-207.

Alemayehu M., 1997. Conservation waste forage development for Ethiopia. Institute for sustainable development. Addis Ababa Ethiopia: 57-60.

Bajracharya, S.K. and Rai, S.K., 2009. Study on the effects of vermicompost on the nodulation and yield of chickpea. Nepal Agricultural Research Journal, 9: 49-55.

Brady N.C., 1996. Nature and properties of soil, 10th Edition. Prantice Hall India Pvt. Ltd., New Dehli. pp 291.

Chang C., Sommerfeldt, T.G. and Entz, T., 1991.Soil Chemistry after elevenannual application of cattle feedlotmanure. Journal of Environmental Quality, 20: 475-480.

Chung R., Wang, C.H., Wang, Y., Wang, R.S., Wang, C.W. and Wang, Y.T., 2000. Influence of organic matterand inorganic fertilizer on the growthand nitrogen accumulation of cornplants. Taiwan Journal PlantNutrition, 23(3): 297-311.

Cochran, W.G. and Cox, G.M., 1959. Experimental Designs. Asia Publishing House, Bombay.

Dordas, C.A., Vlachostergios, D.N. and Lithourgidis, A.S., 2012. Growth dynamics and agronomic-economic benefits of peaoat and pea-barley intercrops. Crop \& Pasture Science, 63: 45-52.

Eaglesham, A.R.J., Ayanaba, A., RangaRao, V. and Eskew, D., 1981.Improving the nitrogen nutrition of maize by intercropping with cowpea.Soil Biology and Biochemistry, 13(2): 169-171.

Gomez, K.A. and Gomez, A.A., 1984. Statistical 
procedures for agricultural research. John Wiley \& Sons, New York.

Goulden, C.H., 1952. Methods of Statistical Analysis. John Wiley and sons Inc., New York.

Hauggaard-Nielsen, H., Ambus, P. and Jensen, E.S., 2001.Interspecific competition, $\mathrm{N}$ use and interference with weeds in pea-barley intercropping. Field Crops Research, 70: 101-109.

Khan, V.M., Ahamad, A., Yadav, B.L. and Irfan, M., 2017. Effect of vermicompost and biofertilizers on yield attributes and nutrient content and it's their uptake of cowpea [Vignaunguiculata Walp.].International Journal of Current Microbiology and Applied Sciences, 6(6): 1045-1050.

Kuepper G. and Gegner, L., 2004. Organic crop production overview.ATTRA of National Centre for Appropriate Technology.Arkansa.Retrieved from https://www.attra.ncat.org on $23^{\text {rd }}$ May, 2019.

Lithourgidis, A.S., Dordas, C.A., Damalas, C.A. and Vlachostergios, D.N., 2011. Annual intercrops: an alternative pathway for sustainable agriculture. Australian Journal of Crop Science, 5(4): 396-410.

Moghaddam, A., Raza, A., Vollmann, J., Ardakani, M.R., Wanek, W., Gollner, G. and Friedel, J.K., 2014. Biological nitrogen fixation and growth parameters correlations of alfalfa (Medicagosativa L.) genotypes under organically manged fields with limited irrigation. 'Buiding Organic Bridges', at the Organic World Congress, 2014, 13-15 Oct., Istanbul, Turkey.687-
690.

Patra, B.C., Mandal, B.B., Mandal, B.K. and Padhi, A.K., 1999. Suitability of maize based intercropping systems. Indian Journal of Agricultural Sciences, 69: 759762.

Puneeth Raj, M.S. and Vyakaranahal, B.S., 2014. Effect of integrated nutrient and micronutrients treatment onplant growth parameters in oat cultivar (AvenasativaL.).International journal of plant sciences, 9(2):397-400.

Rajkhowa, D.J., Gogoi, A.K., Kandali, R. and Rajkhowa, K.M., 2000. Effect of vermicompost on green gram nutrition.Journal of the Indian Society of Soil Science, 48(1): 207-208.

Tomati, U., Grappelli, A. and Galli, E., 1995. The hormone lie effect of earthworm casts on plant growth. Biology and Fertility of Soils, 5: 288-294.

Vasanthi, D. and Kumaraswamy, K., 1996. Organic farming and sustainable agriculture.National Seminar. G.B.P.U.A.T., Pantnagar. p: 40.

Verdelli, D., Acciaresi, H.A. and Leguizamón, E.S., 2012. Corn and soybeans in a strip intercropping system: crop growth rates, radiation interception, and grain yield components. International Journal of Agronomy, 2: 1-17.

Yang, C., Fan, Z. and Chai, Q., 2018.Agronomic and economic benefits of pea/maize intercropping systems in relation to $\mathrm{N}$ fertilizers and maize density. Agronomy, 8: 52.

\section{How to cite this article:}

Biswas S., K. Jana, R. Khan, R. K. Agrawal and Puste A. M. 2019. Periodic Dry Matter Accumulation and Crop Growth Rate of Oat and Lathyrus As Influenced By Integrated Nutrient Management in Intercropping Systems. Int.J.Curr.Microbiol.App.Sci. 8(08): 26752686. doi: https://doi.org/10.20546/ijcmas.2019.808.310 